fourth report the Industrial Research Association, Ltd., of Johannesburg, deals with industry in South Africa. This last-named country is regarded as one of great potentialities, most of the South African wool, much tobacco, as well as copper, tin, lead and other metals, being at present processed overseas. Processing of bagasse to high-grade paper, artificial wool and plastics, also offers considerable scope.

\section{Anthropometry in Ceylon}

A RECENT issue of the Ceylon Journal of Science (Section G, Anthropology, 4, Part 1, October 1949) contains four anthropometric studies of the peoples of Ceylon : P. K. Chanmugan compares the metrical traits of a hundred adult male subjects (fifty Sinhalese and fifty Ceylon Tamils); and $H$. Cullumbine discusses the muscular development, physique and stature of a total sample of seven thousand individuals in relation to age, sex, race, environment and economic status. A shortcoming of the first study is that it contains no clear reference to the technique of measurement followed, and the validity of some of the comparisons in the rather carelessly edited text, as opposed to the tables, is open to doubt. The Tamil means for weight, sitting height, hip diameter, hand length, lower leg length, foot breadth and head length are significantly greater, and for head breadth significantly less, than the corresponding Sinhalese values. There seems to be no justification for extending, as the author does, the scope of the term "Mediterranean race" to cover these two peoples, particularly in view of the brachycephaly displayed by the Sinhalese. Cullumbine's material was collected in the course of a six-month physical and nutritional survey of the population of Ceylon undertaken in 1947-48, and it has benefited much by a comprehensive and up-to-date statistical analysis. The development of the arm muscles in the two sexes attains its maximum during early adulthood and is related to differences in race, usage and occupation. That of the muscles of the leg is little affected by age or race, but varies with economic status. The effects of age, sex, race, environment and economic level on the distribution among individuals of five types of physique or body build (assessed in terms of weight and height) are estimated by the use of the $\chi^{2}$ test. Although the distributions of both physique and stature are influenced by environment, racial differences persist when the environmental factor is eliminated. Physique is not significantly differentiated at the various economic levels, but a taller stature tends to be associated with a higher family income.

\section{Magnetic Anomaly around Warsaw}

A MAGNETIC survey of the magnetic anomaly in the region around Warsaw is described in No. 12 (pp. 38, 1949) of Prace Obserwatorium Geofizycznego w Swidrze (or Travaux de l'Observatoire Géophysique a Swider, to quote the French name of a publication in which a French translation accompanies the Polish text). This anomaly was among the chief of those disclosed by the Polish magnetic survey, executed by the late Prof. Kalinowski, of epoch 1928.5; but in that survey the network of points surveyed was too open to enable the detailed isomagnetic lines over the anomalous region to be drawn. At his suggestion, his deughter, now Mme. E. Kalinowska-Widomska, made a more detailed survey of the region and has recorded the tables of observations, with a series of magnetic maps, in this publication. Measurements of horizontal and vertical magnetic force $(H, Z)$ were made with Schmidt balances at 184 stations; the work was interrupted by the Second World War, in which the variometers were destroyed, and has been completed since the War with new instruments. The survey covers a region of about $40 \mathrm{~km}$. in radius, centred on Swider, and including Warsaw. The isomagnetic maps show the 1938.5 distribution of $H$ and $Z$ over this region, the normal course of the $H$ and $Z$ isomagnetic lines, and the isanomals.

\section{A Century of Public Library Service in Britain}

THE pamphlet "A Century of Public Library Service" (pp. 32 ; London: Library Association, 1949. 1s. ; 10s. per doz.), issued by the Library Association in connexion with the celebration on August 14, 1950, of the centenary of the first Publio Libraries Act, is addressed to the general public as well as to library authorities and those responsible for the day-to-day conduct of the public libraries. In view, however, of the part which some, at least, of the public libraries must play in securing the improvement in the national central scientific libraries and information services, as suggested by the Royal Society's Scientific Information Conference in 1948, the pamphlet is not without interest to the man of science and the technologist. Although one in every four members of the community uses a public library and only sixty thousand people are in areas without library services, the pamphlet shows that standards of service vary considerably, and many library services are inadequate and ill-sup. ported; it does not appear that substantial progress has yet been made in removing the defects to which the McColvin Report directed attention in 1942. There are now 590 library authorities, with twenty. three thousand service points, twelve million registered borrowers and forty-two million books in stock, from which 294,000,000 issues were made in 1949 . Expenditure in 1918, however, was only $f 6,710,293$, and the average expenditure in 1947-48 was only $8 \frac{1}{2} d$. per head of population. Even in boroughs with a population of more than 150,000 the range of expenditure was $1 s$. $4 \frac{1}{2} d$. to $6 \frac{1}{6} d$.; in boroughs of $50,000-150,000$ it was $1 s .5 \frac{1}{2} d$. to $3 \frac{3}{4} d$., and in boroughs less than $50,000,1 s$. $8 d$. to $2 \frac{1}{2} d$. In the counties the range of average expenditure was similarly varied, namely, $1 s .6 d$. to $3 d$. per head. The pamphlet, among its suggestions for appraising standards and the improvement of service, estimates that for a population of fifty thousand an average expenditure of $1 s .9 d$. per head is required for new books, apart from replacement of worn copies and older books. These suggestions claim the attention of users of the public library service, as well as of the library staff, for it is obvious that the existence of such disparities, and even anomalies, is a hindrance to the building of an effective national system of co-operation, whether in relation to scientific and technical libraries or in any other field.

\section{Museums and Education}

Dr. D. A. AllaN, director of the Royal Scottish Museum, Edinburgh, gave a lecture recently at the Royal Society of Arts on "Museums and Education" (J. Roy. Soc. Arts, Nov. 4). At the outset, Dr. Allan affirms that museums are education. They exist only to further it; they can be neither provided, maintained, nor utilized without it. Education is the preparation for living, and for living, if possible, the good and complete life. Living and learning are 